\title{
The Right Side of the Sixties: Reexamining Conservatism's Decade of Transformation
}

\author{
Elizabeth Tandy Shermer \\ Loyola University Chicago, eshermer@luc.edu
}

Follow this and additional works at: https://ecommons.luc.edu/history_facpubs

Part of the History Commons

\section{Author Manuscript}

This is a pre-publication author manuscript of the final, published article.

\section{Recommended Citation}

Shermer, Elizabeth Tandy. The Right Side of the Sixties: Reexamining Conservatism's Decade of Transformation. The Journal of American History, 100, 2: , 2013. Retrieved from Loyola eCommons, History: Faculty Publications and Other Works, http://dx.doi.org/10.1093/jahist/jat350

This Book Review is brought to you for free and open access by the Faculty Publications and Other Works by Department at Loyola eCommons. It has been accepted for inclusion in History: Faculty Publications and Other Works by an authorized administrator of Loyola eCommons. For more information, please contact ecommons@luc.edu.

\section{(c) $($ ) $\ominus$}

This work is licensed under a Creative Commons Attribution-Noncommercial-No Derivative Works 3.0 License. (c) Oxford University Press, 2013. 
Elizabeth Tandy Shermer

eshermer@1uc.edu

Book Review

Laura Jane Gifford and Daniel K. Williams (eds.). The Right Side of the Sixties: Reexamining Conservatism's Decade of Transformation. New York. Palgrave Macmillian. 2012. ISBN 1137014784.

Laura Gifford and Daniel Williams promise the Right Side of the Sixties: Reexamining Conservatism's Decade of Transformation's twelve essays will advance scholarship on conservatism beyond the movement's "reaction against liberalism" (4) and headlining politicians. Conservatives, they maintain, triumphed because the grassroots "contested the future of their movement...[,] discovered what they really believed" (265), and drove the "shifts and transformations" (4), which produced a Right proclaiming itself colorblind, antisecular, and worldly.

Everyday 1960s conservatives displayed an impressive internationalism. Gifford notes the Christian Anti-Communism Crusade sent publications and started schools in and outside the US. American attendees came from the white upper-middle and professional classes, the stratum where Michael Brenes discovered defense workers decrying budget cuts. Unemployment frightened these technocrats, who considered themselves on democracy's frontlines. But globalization triggered Evangelical existentialism. The laity, Andrew Preston demonstrates, recognized times had changed but embraced traditional values for earthly salvation. "Peace through strength, universal nationalism,...local autonomy and globalization" (223) girded them for a new geopolitical order and later became policymakers' prescriptions.

Grassroots' agency appears in few other essays. National Review's Bill Buckley purged the movement of anticommunist extremists, the ultras, who Samuel Brenner emphasizes, largely agreed with mainstream leaders. Buckley, Seth Offenbach shows, also rallied the Right around victory in Vietnam to keep the movement together after 1964. Jason Stahl shows high-minded intellectuals responsible for think tanks assailing liberal objectivity and proclaiming themselves a conservative competitor in what they called "marketplace of ideas." Top lawyers, Robert Daniel Rubin underscores, ensured Orthodox Jews received federal funding for the yeshivas built during their 1960s revival. And Ordinary Southerners were not the ones adapting massive resistance to colorblind conservatism. The Mississippi Citizens' Council's radio and television broadcasts, Stephanie Rolph's evidence indicates, gave prominent conservatives a podium to declare their cause race-neutral. Likewise, Margaret Freeman has the national Pan Hellenic Council's collegiate Protestant elite demanding the freedom to associate to preserve the lily-white Greek system.

Major politicians more than pepper this volume. Spiro Agnew, Justin Coffey emphasizes, received the vice-presidential nod because of his moderate reputation. The grassroots did not push him to the right. Like many white ethnic suburbanites, Agnew found himself there as political fault lines shifted around him. Agnew of course ran with Richard Nixon, who Williams credits with unintentionally uniting Catholics and Evangelicals into the ecumenical Religious 
Right. Yet Joshua Farrington's excellent essay on conservative Black nationalism hardly ends with Nixon presiding over conservative unanimity. Nixon's programs for minority business loans thrilled Black conservatives, who considered capitalism the conduit for Black Power. But a new crop of white Republicans began to reject initiatives to nurture free-enterprise conservatism among minorities, who received markedly less support thereafter.

Thus, Gifford and Williams rightly have pointed out that 1960s "Conservatism experienced a few major setback" (2). Yet these essays scarcely show "in the end, conservatives triumphed" (2). This volume instead laudably covers a range of conservatives missing from standard accounts and proves the movement was never a monolith orchestrated either from the top-down or driven from the bottom-up. 